\title{
Gambaran Hubungan Regimen Dosis dan Efek Samping Kemoterapi pada Pasien Kanker di RSUD Prof. Dr. Margono Soekarjo Purwokerto Periode Bulan Januari-Februari Tahun 2019
}

\author{
The Description of Relationship of Dosage Regimen and Side Effects of \\ Chemotherapy in Cancer Patients at RSUD Prof. Dr. Margono Soekarjo \\ Purwokerto Period of January-February in 2019
}

\author{
Endang Darmawan1, Reina Melani1 ${ }^{*}$, Budi Raharjo² \\ ${ }^{1}$ Magister Farmasi Klinis, Universitas Ahmad Dahlan \\ 2 RSUD Prof. Dr. Margono Soekarjo Purwokerto \\ Corresponding author: Reina Melani: rmsmktelu@yahoo.com
}

Submitted: 15-07-2019 Revised: 30-07-2019 Accepted: 31-08-2019

\begin{abstract}
ABSTRAK
Pengobatan kanker dikenal beberapa cara, salah satunya adalah kemoterapi, yaitu pengobatan dengan menggunakan obat-obatan yang dapat menghambat atau membunuh sel-sel kanker. Pengobatan dengan kemoterapi banyak menimbulkan efek samping. Tujuan penelitian yaitu untuk mengetahui gambaran efek samping kemoterapi pasien kanker di RSUD Prof Dr Margono Soekarjo Purwokerto dan mengetahui hubungan antara regimen dosis terhadap efek samping kemoterapi. Penelitian ini menggunakan rancangan secara prospektif dengan pendekatan study metode cross sectional. Gambaran efek samping kemoterapi yang banyak terjadi di RSUD Prof. Dr Margono Soekarjo Purwokerto pada pasien 10 besar kanker periode bulan Januari - Februari 2019 adalah alergi sebanyak 15 pasien (10\%), disusul dengan mual sebanyak 11 pasien (7.3\%) sedangkan leukopenia dan neutropenia masing-masing sebanyak 5 pasien (4.7\%). Kesimpulan pada peneltian ini yaitu bahwa ada hubungan yang signifikan antara pemberian obat kemoterapi terhadap terjadinya efek samping setelah menjalani kemoterapi $(\mathrm{p}<0,05)$.
\end{abstract}

Kata kunci: kanker, regimen dosis, efek samping obat, kemoterapi.

\begin{abstract}
Cancer treatment is known by several methods, one of them is chemotherapy, which is treatment using drugs that can inhibit or kill cancer cells. However, many problems occur, namely the emergence of side effects in chemotherapy. The purpose of this study is to describe the side effects of chemotherapy in cancer patients at RSUD Prof. Dr. MargonoSoekarjo in Purwokerto and find out the relationship between the dosage regimen on the side effects of chemotherapy.This study uses by prospective data collection with a cross sectional method study approach.The description of the side effects of chemotherapy that occur a lot at RSUD Prof. Dr. Margono Soekarjo Purwokerto in patients with 10 major cancers during the period of January - February 2019 were allergic as many as 15 patients (10\%), followed by nausea as many as 11 patients (7.3\%) while leukopenia and neutropenia were 5 patients $(4.7 \%)$ respectively. The results of the analysis can be concluded that there is a significant relationship between the administration of chemotherapy drugs to the occurrence of side effects after undergoing chemotherapy $(\mathrm{p}<0,05)$.
\end{abstract}

Keywords: cancer,dosage regimen,drugs' effects, chemotherapy.

\section{PENDAHULUAN}

Kanker merupakan masalah kesehatan di seluruh dunia dan sebagai penyebab utama morbiditas dan mortalitas di negara maju (Belkahla et al., 2017). Secara keseluruhan angka kejadian kasus kanker di dunia mencapai 14,1 juta kasus baru dan 8,2 juta kematian pada tahun 2012 (Ferlay et al., 2014).Di Indonesia, data terakhir dari Riset Kesehatan Dasar (Riskesdas) 2013 yang diterbitkan Badan Penelitian dan Pengembangan Kesehatan (Balitbangkes) Kementrian Kesehatan RI menyatakan bahwa prevalensi kanker mencapai $0,14 \%$ penderitanya menjadi 347.792 
penduduk (Medicinus, 2016). WHO memperkirakan insiden kanker di Indonesia adalah 180 per 100.000 penduduk (Sukardja,2000).

Kanker adalah sekelompok penyakit yang ditandai dengan pertumbuhan sel yang tidak teratur serta menembus jaringan-jaringan disekitarnya kemudian sel akan berproliferasi dan menyebar dari tempat asal atau tempat utama ke tempat lain di dalam tubuh (Pecorino, 2012). Pengobatan kanker dikenal beberapa cara yaitu terapi utama dan terapi tambahan (adjuvant). Terapi utama adalah terapi yang ditujukan pada penyakit kanker itu sendiri yaitu dapat dengan cara bedah, radioterapi, kemoterapi, hormonoterapi dan bioterapi. Terapi tambahan (adjuvant) adalah terapi yang ditambahkan pada terapi utama untuk menghancurkan sisa sel-sel kanker yang mikroskopik yang mungkin masih ada.Tidak jarang walaupun pada terapi utama penderita kelihatan telah bebas kanker setelah beberapa lama timbul residif atau metastase.Ini berarti waktu selesai terapi utama masih ada sisa kanker yang mikroskopik.Adapun terapi tambahan ini dapat berupa adjuvant kemoterapi, adjuvant hormonterapi, adjuvant radioterapi dan adjuvant operasi (Sukardja, 2000).

Kemoterapi yaitu pengobatan dengan menggunakan obat-obatan yang dapat menghambat atau membunuh sel-sel kanker(Remesh, 2012). Kemoterapi menyebabkan beberapa efek samping. Efek samping kemoterapi bervariasi tergantung regimen kemoterapi yang diberikan. Berdasarkan National Cancer Institute, efek samping yang dapat terjadi akibat kemoterapi antara lain mual, muntah, diare, alopesia, trombositopenia, neuropati, myalgia. Selain itu dapat berupa toksisitas hematologi seperti anemia, neutropenia, dan trombositopenia. Toksisitas gastrointestinal seperti anoreksia, nausea, dan vomiting. Toksisitas oral seperti stomatitis, disfagia, diare, ulserasi mulut, oesofagitis, dan proctitis dengan nyeri serta pendarahan. Toksisitas folikel rambut berupa alopesia serta toksisitas sistem syaraf berupa neurotoksisitas (Remesh, 2012). Salah satu efek samping yang sering ditemukan akibat kemoterapi adalah alopesia. Dalam suatu penelitian yang dilakukan Kiebert et al, didapatkan lebih dari $80 \%$ wanita yang menjalani kemoterapi mengatakan bahwa alopesia merupakan aspek paling traumatik dari kemoterapi yang dijalaninya dan $8 \%$ pasien bahkan berhenti dari kemoterapi karena ketakutannya akan mengalami alopesia. Tujuan penelitian yaitu untuk mengetahui gambaran efek samping kemoterapi pasien kanker di RSUD Prof Dr Margono Soekarjo Purwokerto dan mengetahui hubungan antara regimen dosis terhadap efek samping kemoterapi.

\section{METODOLOGI}

Penelitian ini dilakukan pada semua pasien rawat inap diruang perawatan Bougenville dengan diagnosis kanker yang mendapatkan obat anti kanker di RSUD Prof. Dr Margono Soekarjo Purwokerto selama kurun waktu Januari-Februari 2019 sebanyak 150 pasien. Sampel yang masuk dalam penelitian ini adalah populasi yang memenuhi kriteria inklusi.Teknik pengambilan sampel dengan menggunakan metode purposive sampling, yaitu semua pasien yang memenuhi kriteria diambil sebagai sampel penelitian.

Kriteria Inklusi meliputi pasien yang terdiagnosis menderita kanker yang mendapatkan terapi antikanker di RSUD Prof Dr Margono Soekarjo Purwokerto dan data rekam medisnya lengkap.Kriteria ekslusi yaitu data rekam medis yang tidak lengkap dan tidak dapat terbacas

\section{Analisis Data}

Analisis data dilakukan secara stastistik deskriptif terhadap karakteristik subjek penelitian. Analisis univariat dilakukan terhadap karakteristik pasien yang dibuat dengan menghitungkan jumlah dan prosentase berdasarkan usia pasien, Jenis kelamin, tingkat pendidikan dan pekerjaan. Sampel dianalisis terhadap semua variabel bebas dan variabel terikat untuk menentukan perbandingan munculnya efek samping akibat kemoterapi berdasarkan jenis obat, regimen dosis, dan frekuensi kemoterapi pada 10 besar pasien kanker yang menjalani pengobatan di RSUD Prof Dr Margono Soekarjo Purwokerto pada bulan Januari-Februari 2019.

Jenis hipotesis yang digunakan adalah hipotesis korelatif (hubungan antara kesesuaian dosis, obat, dan frekuensi kemoterapi dengan kejadian munculnya efek samping. Skala penelitian yang digunakan adalah komparatif kategorik karena variabel bebas dan variabel 
Tabel I. Karakteristik sosio demografi pasien kanker secara keseluruhan sebanyak 150 pasien dari 10 besar jenis kanker yang terjadi dan menjalani kemoterapi di RSUD Prof. Dr Margono Soekarjo Purwokerto periode Januari-Februari 2019

\begin{tabular}{lcc}
\hline \multicolumn{1}{c}{ Variabel } & Jumlah (n) & Prosentase (\%) \\
\hline Usia & & \\
$\quad<40$ tahun & 36 & $24,0 \%$ \\
$>40$ tahun & 114 & $76,0 \%$ \\
$\quad$ Total & 150 & $100,0 \%$ \\
Jenis Kelamin & & \\
$\quad$ Perempuan & 93 & $62,0 \%$ \\
$\quad$ Laki-laki & 57 & $38,0 \%$ \\
$\quad$ Total & 150 & $100,0 \%$ \\
Pendidikan & & \\
$\quad<9$ tahun & 65 & $43,3 \%$ \\
$\quad>9$ tahun & 85 & $56,7 \%$ \\
$\quad$ Total & 150 & $100,0 \%$ \\
Pekerjaan & & \\
$\quad$ Bekerja & 109 & $72,7 \%$ \\
$\quad$ Tidak Bekerja & 41 & $27,3 \%$ \\
Total & $\mathbf{1 5 0}$ & $\mathbf{1 0 0 , 0 \%}$ \\
\hline
\end{tabular}

terikat berskala nominal. Uji statistik yang digunakan adalah uji Kruskal Wallis.

\section{HASIL DAN PEMBAHASAN}

Penelitian ini dilakukan di ruang perawatan Bougenville RSUD Prof. Dr Margono Soekarjo Purwokerto Januari-Februari 2019.

\section{Karakteristik Sosio-Demografi Pasien}

Pasien yang menjadi subyek penelitian ini adalah pasien 10 besar kanker yang menjalani kemoterapi di RSUD Prof Dr Margono Soekarjo periode bulan Januari- Februari 2019. Adapun gambaran karakter sosio-demografi pasien yang meliputi usia, jenis kelamin, pendidikan dan pekerjaan (Tabel I).

Berdasarkan Tabel I menunjukkan bahwa usia $<40$ tahun sebanyak 36 pasien (24\%) dan usia $>40$ tahun sebanyak 114 pasien (76\%). Hal ini sejalan dengan penelitian yang dilakukan Apdani (2011), yang menyatakan bahwa semakin bertambahnya usia memungkinkan paparan zat karsinogen yang semakin bertambah dan terakumulasinya berbagai perubahan genetik pada tubuh. Ketika manusia menua, resiko penyakit kronis bertambah dan pertambahan ini sejalan dengan teori penuaan. Kejadian kanker juga menurun pada usia tua, sesudah mengalami kenaikan pada usia dewasa (Ukraintseva, 2003). Kanker ovarium ditemukan terjadi banyak pada usia 0-83 tahun. Pada usia pertengahan di Swedia didiagnosis kanker ovarium (Gzhang et al., 2018). Penelitian yang lain menyatakan bahwa beberapa jenis kanker terjadi pada usia pertengahan sampai 70 tahun, kemudian menurun kira-kira $41 \%$ di Amerika Serikat, kemudian setelah memasuki usia 90 tahun, kanker bukanlah penyebab suatu penyakit atau kematian (White, et al., 2015). Secara umum, manusia terkena kanker pada usia 50 tahun dan setelahnya akan terjadi penurunan (White et al., 2015).

Berdasarkan jenis kelamin menunjukkan bahwa laki-laki sebanyak 57 pasien (38\%) dan wanita yaitu sebanyak 93 pasien (62\%). Perbedaan jenis kelamin pada kerentanan kanker, keganasan hematologi pada umumnya dapat terjadi pada kanker yang lain. Pada LMNH misalnya perbandingan angka kejadiannya sama antara laki-laki dan wanita dewasa, sedangkan pola penyakit autoimun lebih banyak terjadi pada wanita (Dorak, 2012). Laki-laki lebih banyak kemungkinan terkena kanker dibanding wanita terutama pada kanker prostat, paru-paru dan kanker kolon(White, et al 2015).

Gambaran selanjutnya berdasarkan pendidikan pasien, diperoleh data berupa pasien dengan pendidikan $<9$ tahun (tidak sekolah/ tidak tamat SD, dan SMP) sebanyak 65 pasien (43.3\%) dan pasien dengan pendidikan > 9 tahun (SMA, Diploma dan Sarjana) yaitu 
Endang Darmawan

Tabel II. Gambaran siklus kemoterapi yang dijalani pasien 10 besar kanker di RSUD Prof. Dr Margono Soekarjo Purwokerto Periode Januari-Februari 2019

\begin{tabular}{ccc}
\hline No & Jumlah Siklus & Jumlah Pasien \\
\hline 1. & 1 & 84 \\
2. & 2 & 19 \\
3. & 3 & 12 \\
4. & 4 & 12 \\
5. & 5 & 11 \\
6. & 6 & 5 \\
7. & 7 & 4 \\
8. & 9 & 1 \\
9. & 11 & 1 \\
10. & 13 & 1 \\
Total & & $\mathbf{1 5 0}$ \\
\hline
\end{tabular}

sebanyak 85 pasien (56.7\%). Penelitian lain di Kentucky menemukan hubungan antara kematian akibat kanker paru-paru dengan tingkat kelulusan sekolah menengah. Temuan ini menunjukan bahwa Kentucky menekankan peningkatan $6.2 \%$ kelulusan pada sekolah menengah untuk berkontribusi pada pengurangan mortalitas kanker paru-paru (Gross, 2010). Adapun keterkaitan antara tingkat pendidikan dengan kejadian kanker serviks, terdapat hubungan yang kuat, dimana kanker serviks cenderung lebih banyak terjadi pada wanita yang berpendidikan rendah dibanding dengan wanita yang berpendidikan tinggi (88.9 \%). Wanita yang berpendidikan rendah kemungkinan kurang memperhatikan tentang kesehatan terutama kebersihan alat kelaminnya maka akan memiliki resiko terkena kanker serviks (Damayanti, 2013). Penelitian lain yang relevan berkaitan dengan hubungan tingkat pendidikan dan kanker adalah menyatakan bahwa dari 100 sampel pada pasien kanker paru-paru dinyatakan bahwa, $55 \%$ berpendidikan rendah dan terkena kanker paru-paru, sisanya adalah berpendidikan diploma dan sarjana lebih sedikit yang terkena penyakit kanker paru-paru (Lawson et al , 2009)

Berdasarkan jenis pekerjaan diperoleh hasil yaitu pada kelompok bekerja sebanyak terdapat 109 pasien (72.7\%) dan pada kelompok tidak bekerja yaitu sebanyak 41 pasien (27.3\%). Hal ini sejalan dengan penelitian yang dilakukan oleh Yulia (2012) yang menyatakan bahwa responden yang memiliki aktivitas rutin atau bekerja yaitu sebanyak 39 orang (61.9\%) sedangkan pada responden yang tidak memliki aktivitas rutin atau tidak bekerja sebanyak 24 orang (38.1\%). Menurut penelitian, faktor pekerjaan dapat meningkatkan inisiasi perkembangan kanker payudara (Fenga, 2016).

\section{Siklus Kemoterapi Pasien}

Seluruh pasien yang menjalani kemoterapi dikelompokkan berdasarkan jumlah siklus kemoterapi dari 10 besar kanker yang terjadi di RSUD Prof. Dr. Margono Soekarjo Purwokerto Periode Januari- Februari 2019.Kemoterapi dilakukan paling banyak 4-6 siklus, dengan peningkatan toksisitas yang signifikan jika diberikan lebih dari 6 siklus ( Kemenkes, 2017). Gambaran siklus kemoterapi (Tabel II).

Berdasarkan desain studi data dikumpulkan dari 137 tempat praktik onkologi komunitas yang dipilih secara acak di seluruh Amerika Serikat dengan berbagai macam kanker terjadi efek samping pada siklus pertama kemoterapi yaitu neutropenia demam $14 \%$, dan neutropenia demam parah $9 \%$ pada pasien kanker ovarium. Analisis multivarian menunjukkan bahwa regimen berbasis antrasiklin adalah faktor resiko independen yang paling penting untuk kejadian neutropeni siklus pertama (Creford, 2003).Faktor resiko independen lainnya adalah anemia selama pengobatan, penggunaan regimen berbasis platinum dan luas area permukaan tubuh yang rendah. Regimen berbasis taxan dikaitkan dengan neutropenia pada demam siklus pertama.Jadi dapat disimpulkan bahwa kejadian neutropeni paling sering selama siklus pertama 
Tabel III. Regimen kemoterapi Pasien 10 besar kanker yang menjalani kemoterapi di RSUD Prof. Dr Margono Soekarjo Purwokerto periode Januari- Februari 2019

\begin{tabular}{|c|c|c|}
\hline Regimen Terapi & Jumlah (n) & Presentase (\%) \\
\hline Carboplatin + Paclitaxel & 39 & 26,0 \\
\hline Cisplatin + Paclitaxel & 18 & 12,0 \\
\hline Metotrexat + Leucoverin & 16 & 10,7 \\
\hline Oxaliplatin + Cepecetabin & 9 & 6,0 \\
\hline Cyclophosphamid + Doxorubycin + Vincristin + Prednison & 8 & 5,3 \\
\hline Leucoverin + 5 FU & 7 & 4,7 \\
\hline Cyclophosphamid + Paclitaxel & 7 & 4,7 \\
\hline Oxaliplatin + Novorin + 5 FU & 6 & 4,0 \\
\hline Carboplatin & 6 & 4,0 \\
\hline Cylcophosphamid +Doxorubycin + Vincristin & 5 & 3,3 \\
\hline Cyclophosphamid +5 FU + Doxorubycin & 5 & 3,3 \\
\hline Gemcitabin + Cisplatin & 4 & 2,7 \\
\hline Gemcitabin & 4 & 2,7 \\
\hline Bleomycin & 2 & 1,3 \\
\hline Camptothecin + Leucoverin + 5 FU & 2 & 1,3 \\
\hline $\begin{array}{l}\text { Bleomycin + Cyclophosphamide+ Epirubycin + Vincristin + } \\
\text { Prednison }\end{array}$ & 1 & 0,7 \\
\hline Vincristin + Etoposide + Cyclophosphamid & 1 & 0,7 \\
\hline Bleomycin + Etoposide + Cisplatin & 1 & 0,7 \\
\hline Irinotecan + Novorin +5 FU & 1 & 0,7 \\
\hline Oxaliplatin + Leucoverin + 5 FU & 1 & 0,7 \\
\hline Paclitaxel + Doxorubycin & 1 & 0,7 \\
\hline Docetaxel + Cyclophosphamide & 1 & 0,7 \\
\hline Carboplatin + Etoposide & 1 & 0,7 \\
\hline Metotrexat + Etoposide & 1 & 0,7 \\
\hline Carboplatin + Docetaxel & 1 & 0,7 \\
\hline Cisplatin + 5 FU & 1 & 0,7 \\
\hline Cisplatin & 1 & 0,7 \\
\hline Total & 150 & 100,0 \\
\hline
\end{tabular}

kemoterapi kanker, pasien dirawat dengan kemoterapi dosis penuh tanpa perawatan suportif (Creford, 2019).

Penelitian lain sebuah studi retrospektif mengevaluasi data dari 165 pasien dengan kanker indung telur disertai pembedahan dan diikuti 6 siklus kombinasi platinum taxan sebagai kemoterapi menunjukkan keuntungan kemoterapi setelah pembedahan primer mempengaruhi tingkat kebebasan progresif, spesifikasi kanker dan pertahanan total pada pasien kanker indung telur (Seebachter, 2017).

Sejak 2004 regimen yang terdiri dari oxaliplatin dan flourourasil menjadi standar ajuvan terapi pada pasien kanker kolon studium 3.Namun sejak oxaliplatin menyebabkan neurotoksik, dilakukan pengurangan siklus terapi. Penelitian prospektif pada pasien kanker kolon studium 3 dibagi 2 dengan kelompok yang mendapatkan FOLFOX (flourourasil, leukoverin dan oksaliplatin) dan kelompok yang mendapatkan CAPOX (capecetabin dan oksaliplatin) dibandingkan dengan siklus 3 bulan dan 6 bulan hasilnya pasien yang mendapatkan CAPOX 3 bulan lebih efektif terapinya dibandingkan dengan siklus selama 6 bulan terutama pada kelompok resiko rendah (Grothey, 2018).

\section{Variasi Obat Kemoterapi}

Jenis obat yang diberikan yaitu obat berbasis platinumdan jenis obat yang tidak berbasis platinum.Pilihan utama obat berbasis platinum adalah sisplatin, diikuti dengan carboplatin. Obat kemoterapi lini pertama tidak berbasis platinum yang dapat diberikan adalah etoposid, gemsitabin, paklitaksel dan vinoralbin (Kemenkes, 2017). Jenis regimen kemoterapi (Tabel III). 
Tabel IV. Efek samping kemoterapi pada pasien 10 besar kanker yang menjalani kemoterapi di RSUD Prof. Dr Margono Soekarjo Purwokerto periode Januari-Februari 2019

\begin{tabular}{lccl}
\hline Efek Samping & Jumlah (n) & Prosentase (\%) & \multicolumn{1}{c}{ Regimen Kemoterapi } \\
\hline Alergi & 15 & $10 \%$ & TP,LF,PLF,BEP,ILF,PT,P,ML,EM \\
Mual & 11 & $7,3 \%$ & CAF,LF,BEP,ILF,PLF,PT,ML \\
Leukopenia & 5 & $4,7 \%$ & TP,ML \\
Neutropenia & 5 & $4,7 \%$ & TP,ML \\
Depresi sumsum & 4 & $2,7 \%$ & ML.EM, \\
tulang & & & \\
Muntah & 3 & $2 \%$ & ILF,PT,ML \\
Ekstravasasi & 1 & $0,7 \%$ & CAF \\
Nyeri & 1 & $0,7 \%$ & PLF \\
Kesemutan & 1 & $0,7 \%$ & PLF,ILF \\
Rambut rontok & 1 & $0,7 \%$ & PT \\
\hline Diare & 1 & $0,7 \%$ & ILF \\
\hline
\end{tabular}

Keterangan : A : Doxorubisin; C : Cyclofosfamide; E : Etoposide; G : Gemsitabin; P : Sisplatin / Carboplatin / Oksaliplatin; T : Docetaxel / Paclitaxel F : 5 Flouro Urasil; L : Leucoverin; B : Bleomisin; I : Irinotecan; M : Metotreksat

Berdasarkan Tabel III menunjukkan bahwa kombinasi obat kemoterapi yang paling banyak digunakan di RSUD Prof. Dr Margono Soekarjo Purwokerto periode Januari-Februari 2019 adalah kombinasi antara karboplatin dan paklitaksel sebanyak 39 pasien (26\%). Penelitian ini sejalan dengan penelitian yang dilakukan oleh Alfiasari (2007) yang menyatakan bahwa kemoterapi terbanyak yang digunakan pada pasien kanker paru adalah carboplatin-paclitaxel (65 \%).Berdasarkan penelitian yang dilakukan Howley (2017),kombinasi yang paling sering digunakan dalam kemoterapi kanker payudara adalah taxanes yaitu Paclitaxel dan Docetaxel. Kombinasi Leucoverin dan Metotreksat digunakan pada pasien kanker TTG tetapi pada pemberian dosis kemoterapi tidak sesuai dengan guideline dan untuk dosis nya tidak melihat umur, berat badan dan tinggi badan pasien. Dosis yang diberikan sama untuk semua pasien yang menjalani kemoterapi kasus TTG.

Pemberian terapi adjuvan trastuzumab selama 9 minggu diikuti 3 siklus flourourasil dan epirubisin dievaluasi kemanjurannya dibandingkan dengan pemberian trastuzumab selama 1 tahun. Hasilnya pemberian trastuzumab 9 minggu tidak kalah dengan yang pemberian 1 tahun bahkan kondisi kesehatan jantung lebih baik pada kelompok 9 minggu (Joennsu, 2018).

\section{Gambaran Efek Samping Kemoterapi}

Pada penelitian ini dilakukan analisis efek samping dan jumlah pasien yang mengalaminya ditemukan ada 11 jenis efek samping dan terjadi pada 25 pasien atau sebanyak $16,7 \%$ dari total 150 pasien. Gambaran efek samping kemoterapi (Tabel IV).

Kemoterapi mempengaruhi semua sel yang tumbuh dan membelah dengan cepat di dalam tubuh, termasuk sel-sel kanker dan selsel normal seperti sel-sel darah baru di sumsum tulang atau sel-sel di mulut, perut, kulit, rambut dan organ reproduksi. Ketika kemoterapi merusak sel-sel normal, maka hal ini akan menyebabkan efek samping (Patel, 2018).

Berdasarkan Tabel IV efek samping kemoterapi yang banyak terjadi adalah alergi sebanyak 15 pasien $(10 \%)$ dan kejadian mual pada 11 pasien $(7,3 \%)$. Penelitian melaporkan adanya hubungan antara alergi dan limfoma atau leukimia akut. Faktanya hanya pada penyakit ini korelasi terkuat dengan status alergi yang dapat dideteksi, sementara penyakit hematologi yang lain dilaporkan sporadis dan kadang-kadang saja (Musolino et al, 2014). Efek samping yang terjadi selanjutnya adalah mual sebanyak 11 pasien (7,3\%). Toksisitas Gasto Intestinal biasa terjadi pada pasien yang menjalani kemoterapi. Anoreksia, mual, muntah setelah kemoterapi itu bukan proses patologi, tetapi agak pada proses fisiologi dimana tubuh 
Tabel V. Hubungan Jenis Obat dengan Kejadian Efek Samping Pasien 10 besar Kanker yang Menjalani Kemoterapi di RSUD Prof Dr Margono Soekarjo Purwokerto Periode Januari - Februari

2019

\begin{tabular}{|c|c|c|c|c|}
\hline \multirow{2}{*}{ Evaluasi Obat } & \multicolumn{2}{|c|}{ Efek Samping } & \multirow[b]{2}{*}{ P Value } & \multirow[b]{2}{*}{ OR CI (95\%) } \\
\hline & Ada & Tidak ada & & \\
\hline Sesuai & 15 & 54 & & \\
\hline Tidak sesuai & 18 & 63 & 0,943 & $0,972(0,448-2,112)$ \\
\hline Total & & 150 & & \\
\hline
\end{tabular}

mencoba menyingkirkan dirinya sendiri dari zat toksik. Reaksi ini dikontrol oleh refleks di pusat muntah (CTZ) dimana zat dilepaskan masuk ke dalam CSF mengaktivasi trigger zone (Ramesh, 2012)Sedangkan leukopenia dan neutropenia masing-masing sebanyak 5 pasien $(4,7 \%)$. Leukopenia dan Neutropenia terjadi pada pasien yang mendapatkan kombinasi Doxetacel dan Cisplatin.Ini sejalan dengan penelitian yang mengatakan bahwa pemberian Docetaxel dapat menyebabkan efek samping Neutropenia dan Leukopenia dengan pemberian taxotere (Docetaxel) $100 \mathrm{mg} / \mathrm{m} 2$.Neutropenia yang disebabkan oleh kemoterapi adalah komplikasi yang umum dalam terapi kanker. Penelitian di jepang pada 291 pasien antara umur 24-84 tahun 291 regimen serta 378 siklus, neutropenia terjadi pada 147 pasien atau 50,5 \% (Hashiguchi, 2015). Angka neutropenia yang terjadi lebih tinggi dibandingkan penelitian tesis ini dikarenkan kanker yang diteliti hanya kanker keganasan ginekologis yang memang pada awal setelah kemoterapi langsung terdeteksi neutropenia.

Kejadian depresi sumsum tulang sebanyak 4 pasien $(2,7 \%)$, efek samping muntah terjadi pada 3 pasien (2\%), kesemutan terjadi pada 1 pasien $(0,7 \%)$ dan selebihnya adalah kejadian ekstravasasi, nyeri, rambut rontok, dan diare masing-masing terjadi pada 1 pasien $(0,7 \%)$. Pada studi retrospektif pasien yang dirawat di 99 praktek onkologi ditemukan kelompok pasien yang diterapi dengan filgastrim dan yang tidak diberikan pegfilgrastim. Hasilnya ada penambahan 1,8\% kejadian demam neutropenia pada pasien yang menerima filgastrim (Morrisson, 2007).

\section{Hubungan Jenis Obat dengan Kejadian Efek Samping Kemoterapi}

Pada penelitian ini, dilakukan analisis pada setiap siklus kemoterapi dengan jumlah total 150 siklus. Pemilihan obat berdasarkan guidelines dari National Comprehensive Cancer Network (NCCN) tahun 2015-2018 dan Pedoman Diagnosa \& Penatalaksanaan di Indonesia (PDPI) untuk kanker paru sedangkan kanker yang lain menggunakan Panduan Penatalaksaan kanker yang diterbitkan oleh Komite Penanggulangan Kanker Nasional Kementrian Kesehatan Republik Indonesia tahun 2018. Hubungan jenis obat dengan kejadian efek samping kemoterapi (Tabel V).

Berdasarkan Tabel $\mathrm{V}$ dilakukan uji statistik dengan uji alternatif Fishers.Diperoleh nilai $\mathrm{P}=0.943, \mathrm{P}>0.05$ (tingkat signifikansi) dengan tingkat kepercayaan 95\%, maka Ho ditolak dan Ha diterima. Hasil analisis dapat disimpulkan bahwa tidak ada hubungan yang signifikan antara pemberian jenis obat kemoterapi terhadap terjadinya efek samping setelah menjalani kemoterapi.Efek samping dari kemoterapi timbul dikarenakan obat antikanker sangat kuat dan tidak hanya membunuh sel-sel kanker akan tetapi juga menyerang sel-sel sehat dalam tubuh, sehingga efek samping seperti rambut rontok, hemoglobin, trombosit dan sel darah putih berkurang dan terjadi mual muntah (Satria, 2015).

\section{Hubungan Regimen Dosis Kemoterapi dengan Efek Samping}

Pada penelitian ini dilakukan hubungan kesesuaian dosis kemoterapi dengan kejadian munculnya efek samping pada pasien 10 besar kanker yang menjalani kemoterapi di RSUD Prof. Dr Margono Soekarjo periode bulan Januari-Februari 2019 dengan nilai toleransi tidak lebih dari 5\%.Hubungan regimen dosis kemoterpai dengan efek samping (Tabel VI).

Berdasarkan Tabel VI dilakukan uji statistik dengan uji alternatif dengan Kruskal Wallis test Dilihat dari nilai $\mathrm{P}=0.034, \mathrm{P}<0.05$ (tingkat signifikansi) dengan tingkat kepercayaan 95\%, maka Ho diterima dan $\mathrm{Ha}$ ditolak. Hasil analisis dapat disimpulkan bahwa 
Tabel VI. Hubungan Regimen Dosis kemoterapi dengan Efek Samping

\begin{tabular}{|c|c|c|}
\hline Regimen Dosis Kemoterapi & $\mathbf{n}$ & Efek Samping \\
\hline \multicolumn{3}{|l|}{ Regimen Tunggal } \\
\hline Bleomycin & 2 & \multirow{4}{*}{$\begin{array}{l}\text { Leukopenia, Mual, Ekstravasasi } \\
\text { Alergi, Nyeri, Kesemutan, Nafsu } \\
\text { makan turun, Rambut rontok, } \\
\text { Depresi sumsum tulang, }\end{array}$} \\
\hline Cisplatin & 1 & \\
\hline Gemcitabin & 4 & \\
\hline Carboplatin & 6 & \\
\hline \multicolumn{3}{|l|}{ Regimen Kombinasi 2} \\
\hline Cisplatin + Carboplatin & 1 & \multirow{12}{*}{$\begin{array}{l}\text { Leukopenia, Mual, Ekstravasasi, } \\
\text { Alergi, Nyeri, Kesemutan, Nafsu } \\
\text { makan turun, Rambut rontok, } \\
\text { Depresi sumsum tulang, }\end{array}$} \\
\hline Cisplatin + Paclitaxel & 18 & \\
\hline Cisplatin + 5 FU & 1 & \\
\hline Docetaxel + Cyclofosfamid & 1 & \\
\hline Etoposid + Metotrexat & 1 & \\
\hline Gemcitabin + Cisplatin & 4 & \\
\hline Carboplatin + Paclitaxel & 39 & \\
\hline Leucoverin + 5 FU & 7 & \\
\hline Metotrexat + Leucoverin & 16 & \\
\hline Oxaliplatin + Cepecetabin & 9 & \\
\hline Paclitaxel + Doxorubicin & 1 & \\
\hline Paclitaxel + Cyclofosfamid & 7 & \\
\hline \multicolumn{3}{|l|}{ Regimen Kombinasi 3} \\
\hline Bleomisin + Etoposid + Cisplatin & 1 & \multirow{8}{*}{$\begin{array}{l}\text { Leukopenia, Mual, Ekstravasasi, } \\
\text { Alergi, Nyeri, Kesemutan, Nafsu } \\
\text { makan turun, Rambut rontok, } \\
\text { Depresi sumsum tulang, }\end{array}$} \\
\hline Camptotexin + Leucoverin +5 FU & 2 & \\
\hline Irinotecan + Leucoverin + 5 FU & 1 & \\
\hline Oxaliplatin + Leucoverin + 5 FU & 7 & \\
\hline Cyclofosfamid + Doxorubicin + Vincristin & 5 & \\
\hline Leucoverin + 5 FU + 5 FU & 1 & \\
\hline Cyclofosfamid + 5 FU + Doxorubicin & 5 & \\
\hline Cyclofosfamid + Etoposid + Vincristin & 1 & \\
\hline \multicolumn{3}{|l|}{ Regimen Kombinasi 4} \\
\hline Oxaliplatin + Leucoverin + 5 FU + 5 FU & 6 & Leukopenia, Mual, Ekstravasasi, \\
\hline $\begin{array}{l}\text { Cyclofosfamid + Doxorubicin + Vincristin + } \\
\text { Prednison }\end{array}$ & 8 & $\begin{array}{l}\text { Alergi, Nyeri, Kesemutan, Nafsu } \\
\text { makan turun, Rambut rontok, } \\
\text { Depresi sumsum tulang, }\end{array}$ \\
\hline \multicolumn{3}{|l|}{ Regimen Kombinasi 5} \\
\hline $\begin{array}{l}\text { Bleomycin + Cyclofosfamid + Epirubycin + } \\
\text { Vincristin + Prednison }\end{array}$ & 1 & $\begin{array}{l}\text { Leukopenia, Mual, Ekstravasasi, } \\
\text { Alergi, Nyeri, Kesemutan, Nafsu } \\
\text { makan turun, Rambut rontok, } \\
\text { Depresi sumsum tulang, }\end{array}$ \\
\hline Total & 150 & \\
\hline
\end{tabular}

ada hubungan yang signifikan antara pemberian obat kemoterapi terhadap terjadinya efek samping setelah menjalani kemoterapi.

\section{Hubungan Frekuensi pemberian kemoterapi dengan Efek Samping}

Pada penelitian ini, dilakukan analisis menggunakan Fisher's untuk melihat apakah ada hubungan antara kesesuaian frekuensi pemberian obat kemoterapi dengan kejadian efek samping kemoterapi pada setiap siklus kemoterapi 10 besar kanker yang menjalani kemoterapi di RSUD Prof. Dr Margono Soekarjo periode bulan Januari-Februari 2019. Hubungan frekuensi pemberian kemoterapi dengan efek samping (Tabel VII).

Berdasarkan Tabel VII dilakukan uji statistik dengan alternatif uji Fisher Exact, dapat dilihat dari nilai p >0.05 (tingkat signifikansi) dengan tingkat kepercayaan 95\% maka H0 diterima dan Ha ditolak. Hasil analisis dengan menggunakan uji Fisher Exact dapat 
Tabel VII. Hubungan Frekuensi pemberian kemoterapi dengan Kejadian Efek Samping setiap siklus pasien 10 besar kanker yang menjalani kemoterapi di RSUD Prof. Dr Margono Soekarjo periode bulan Januari-Februari 2019

\begin{tabular}{lccccc}
\hline \multirow{2}{*}{ Frekuensi } & \multicolumn{2}{c}{ Efek Samping } & \multirow{2}{*}{ P Value } & \multirow{2}{*}{ OR CI (95\%) } \\
\cline { 2 - 3 } & Ada & Tidak ada & & $0,273(0,091-0,820)$ \\
Sesuai & 26 & 109 & & 0,064 & \\
Tidak sesuai & 7 & 8 & & \\
Total & & 150 & & \\
\hline
\end{tabular}

disimpulkan bahwa tidak adanya hubungan yang signifikan antara frekuensi pemberian obat antikanker terhadap terjadinya efek samping setelah menjalani kemoterapi. Semakin banyak frekuensi kemoterapi diberikan maka akan semakin banyak sel kanker yang mengalami kerusakan, demikian juga pada sel yang sehat dalam tubuh. Setelah satu sampai tiga minggu sel sehat pulih akan kembali tetapi mengalami kerusakan yang berarti sehingga akan mengalami penurunan fungsi dan ketahanan tubuh pasien (Melia et al., 2008).

\section{KESIMPULAN}

Tidak ada hubungan yang signifikan antara pemberian jenis kemoterapi terhadap terjadinya efek samping setelah menjalani kemoterapi. ( $P=0,943)$. Ada hubungan yang signifikan antara pemberian regimen kemoterapi terhadap terjadinya efek samping setelah menjalani kemoterapi. $(\mathrm{P}=0,034)$. Tidak ada hubungan yang signifikan antara frekuensi pemberian (siklus) kemoterapi dengan efek samping.

\section{UCAPAN TERIMA KASIH}

Terimakasih penulis ucapkan kepada seluruh pihak yang telah membantu penulis baik secara langsung dan tidak langsung.

\section{DAFTAR PUSTAKA}

Anders Jocobsen, 2002, Dose effect Relationship of Bolus 5-Fluoro Uracil in the Treatment of Advance Colorectal Cancer, Ake Berglund, Bengt Glimelius, Jan-Erik Frodin, Flemming Hansen, Mogens Kjer, Ebbe Lindegaard, Departement of Oncology, Vejle Hospital, DK-7100 Vejle, Denmark

Apdani, R., 2011, Karakteristik Penderita Kanker Paru yang di Rawat Inap di Bangsal Paru RSUD Dr Soedarsono Pontianak Periode 1 Januari - 31 Desember 2010, Skripsi,
Program Studi Pendidikan Dokter, Fakultas Kedokteran dan Ilmu Kesehatan Universitas Tanjungpura, Pontianak.

Arkerstedt, T, Knutsson A, Narusyte J, Svedberg P, Kecklund G, Alexanderson, K ,2015, BMJ Open Night Work and Breast Cancer in Woman: A Swedish Cohort Study.

Belkahla, H.,Herlem, G., Picaud, F., Gharbi, T., Hemadi, M., Ammar, S., Micheu, O., 2017, TRAIL-NP hybrid for cancer therapy : review, Nanoscale.

Bulsink. Arjan, Alex LT, 2013, Characteristic of potential drug-related problem among oncology patients, International journal of Clinical Pharmacy, University of Groningen

Damayanti, Ika Putri 2013, Faktor-faktor yang Berhubungan Dengan Kejadian Kanker Serviks di RSUD Arifin Achmad Pekanbaru Tahun 2008-2010, Jurnal Kesehatan Komunitas Volume 2 No 3.

Fenga C, 2016, Occupational Exposure and Risk of Breast Cancer, Biomedical Report, Spandidos Publication.

Ferlay, J., Soerjomataram, I., Dikshit, R., Eser, S,. Mathers, C., Rebelo, M.,Parkin, D.M..Forman, D., Bray, F., 2014, Cancer incidence and mortality worldwide : soueces, method and major patterns in GLOBOCAN 2012, Int J Cancer 1 : 136(5):E359-86,

Grothey, A, Sobrero A.F, Shields A.F, Yoshino, Paul, J, 2018, Duration of Adjuvant Chemotherapy for Stage III Colon Cancer, The New England Journal of Medicine Vol 378 no 13

Hashiguchi, Y, Kasai Mari, Fukuda Takeshi, Ichimura T, Yasui T, Sumi, T ,2015, Chemotherapy Induced Neutropenia \& Febrile Neutropenia in patient with Gynecologic Malignancy

Howley, K Elaine, 2017, Which Chemotherapy Treatments Are Most Commonly Used for 
Breast Cancer?, US News Health, 16 Nov 2017

Medicinus, 2016. Mengenal Lebih Dalam tentang Kanker, Vol 29, No 1.http : // cme.medicinus.co/file.php/i/IN_DEPTH_ REPORTING_Mengenal_Lebih_Dalam_ten tang_Kanker.pdf.Diakses 5 februari 2018

Morrison, Vicki A, Wong Mitchell, Hershman Dawn, Campos Luis, Ding Beiying, Malin Jennifer, 2007, Observational study of Prevalence of Febril Neutropenia in Patients Who received Filgrastim or Pegfilgrastim Associated With 3-4 week Chemotherapy Regimen in Community Oncology Practices, Journal Of Managed Care Pharmacy Vol 13 No 4

Musolino,C, Allegra A, Minciullo,PL, Gangemi.S, 2014, Allergy and Risk of Hematologic Malignancies Association and Mechanism, Leukimia Research, Elsevier.
Patel, D, Jyoti,2018 Managing Side Effect of Chemotherapy Cancer, diakses pada 25/5/2019

Pecorino, L., 2012, Molecular Biology of Cancer: Mechanisms, Targets, and Therapeutics, Third Edition, Oxford University Press, New York

Remesh,A., 2012, Toxicities of anticancer drugs and its management, International Journal of Basic \& Clinical Pharmacology

Sukardja, Gede dewa , 2000, Onkologi Klinik, Airlangga University Press, Surabaya

Ukraintseva, V,Svetlana, Yashin I Anatoli 2003 Individual Aging and Cancer Risk: How Are They Related?, Demographic Research, Vol 9, Article 8 Page 163-196.

White, C Mary, Holman M Dawn, Henly S.Jane 2015, Age and Cancer Risk, American Journal of Preventive Medicine.

World Health Organization ,2017, Cancer , http : //www.who.int/cancer/en/, diakses pada 14 februari 2018 